\title{
The Effect of Executive Share Ownership, Executive Compensation, and Independent Commissioners on Tax Avoidance
}

\author{
Ellena Nabilah Nur Alisha Ansar, Wahyu Ari Andriyanto, Ekawati Jati Wibawaningsih
}

Economic and Business, University of Pembangunan Nasional Veteran Jakarta, Jakarta, Indonesia

\section{Email address:}

ellena.nabilah@upnvj.ac.id (E. N. N. A. Ansar), wahyuari@upnvj.ac.id (W. A. Andriyanto), ekawati.jati@upnvj.ac.id (E. J. Wibawaningsih)

\section{To cite this article:}

Ellena Nabilah Nur Alisha Ansar, Wahyu Ari Andriyanto, Ekawati Jati Wibawaningsih. The Effect of Executive Share Ownership, Executive Compensation, and Independent Commissioners on Tax Avoidance. Journal of Finance and Accounting. Vol. 9, No. 2, 2021, pp. 28-35. doi: $10.11648 /$ j.jfa.20210902.12

Received: March 20, 2021; Accepted: April 10, 2021; Published: April 16, 2021

\begin{abstract}
Tax is a contribution that mandatory to be paid by personal and corporate taxpayers. The government used that tax for national development. Tax becomes a burden for companies that it is mandatory to be paid. If the companies got larger income so that the taxes that must be paid become larger too. On the other hand, if the companies got smaller income, the taxes that must be paid will become smaller. This leads the companies to avoid taxes that mandatory to be paid by reducing their amount of taxes. This is called tax avoidance. Tax avoidance influenced by several factors such as corporate governance. This study aims to determine the effect of executive share ownership, executive compensation and independent commissioners on tax avoidance. This study uses manufacturing companies listed on the Indonesia Stock Exchange (BEI) for the period 20152019. The sampling technique used was purposive sampling method. The sample used in this study were 52 manufacturing companies listed on the Indonesia Stock Exchange (BEI) during the 2015-2019 period. Hypothesis testing is done using multiple linear regression analysis with the SPSS 26 program and a significance value of 5\%. The results of this study indicate that: (1) Executive share ownership has no significant effect on tax avoidance, (2) Executive compensation has significant positive effect on tax avoidance, (3) Independent commissioners have no significant effect on tax avoidance, (4) Executive share ownership, executive compensation, and independent commissioners are only able to explain tax avoidance by $3,1 \%$.
\end{abstract}

Keywords: Executive Share Ownership, Executive Compensation, Independent Commissioner, Tax Avoidance

\section{Introduction}

Taxes can be interpreted as compulsory contributions that must be paid for both personal taxpayers and corporate taxpayers who are compelling for the benefit of society. In addition, taxes are used by the government for national development so that community welfare can be achieved. Taxes are one of the most largest sources of income for the state but become a burden for companies or a burden on corporate taxpayers. It can be concluded that if the greater the income earned by the company or corporate taxpayer, the greater the amount of tax that must be paid to the state. Vice versa, the smaller the income earned by the company or corporate taxpayer, the smaller the tax that must be remitted to the state.

Public awareness to pay taxes is needed in fulfilling their tax obligations. It is not uncommon for taxpayers to resistance. This resistance can be in the form of passive resistance and active resistance. Tax resistance that does not originate from the taxpayer's initiative but because of the events around it constitutes passive tax resistance. The obstacles that occur can be in the form of tax collection techniques, moral and intellectual growth of the population and economic structure. Meanwhile, active resistance can be said to be tax resistance whose initiative comes from the taxpayer itself. How to do active resistance can be either tax evasion, neglect of taxes, and tax avoidance.

In today's digital era, the practice of economic globalization has been carried out. Economic globalization can be defined as a process in which the world enters a more open economy, without any territorial boundaries between regions. Reporting from Kompas, Sri Mulyani as the minister of state finance of the Republic of Indonesia estimates that 
the globalization process has eliminated the boundaries between regions from one another [28]. According to Sri Mulyani, certain parties can use it to avoid taxes. The finance minister also said we must safeguard the interests of the state through taxation which can be done with international cooperation and good negotiations. Tax avoidance can be done because of loopholes in tax laws.

Some examples of tax avoidance cases that have arisen are cases that have happened to several large multinational companies such as Google, Apple, and IKEA. Some of the companies mentioned stated that the company had complied with all applicable laws and regulations. The aforementioned companies also said tax avoidance could occur because of loopholes arising from the negligence of regulators and policy makers. These companies avoid tax by shifting their income to a place with a small tax rate that originally came from a place with a large tax rate. This means that some parties exploit loopholes in tax law to practice tax avoidance [3].

Reporting from DDTC News, the realization of tax revenue in 2019 was recorded at only $84.4 \%$ of the target of IDR $1,577.56$ trillion [19]. This can be said if the tax revenue target is not achieved. Even though it did not reach the target, the realization of tax revenue in 2019 experienced a growth of 1.4\% compared to the previous year. From this data, it can be said that the tax revenue realization target did not reach the target due to the possibility of taxpayers not fulfilling their tax obligations. Tax itself is a burden for companies that must be paid by companies to the state. Therefore, there will be a tendency for companies to avoid taxes by minimizing or reducing the amount of taxes that must be paid. Efforts to reduce the amount of tax that must be paid are also known as Tax Avoidance.

Tax Avoidance, namely the activity of manipulating profits that aims to reduce the amount of tax that must be submitted to the state. Tax avoidance is included in active tax resistance, which means that the resistance comes from the taxpayer's own initiative. Companies do tax avoidance as an effort to minimize the tax burden imposed on the company. Tax avoidance that is carried out does not conflict with and does not deviate from the regulations of the applicable tax laws. This action is taken so that the company continues to receive a large amount of profit but the tax that needs to be deposited is smaller than it should be. Tax avoidance causes the state to suffer losses. In addition, the company views tax avoidance as capable of bringing economic benefits to the company [2]. Tax avoidance can occur due to factors that can influence corporate governance, such as Executive Share Ownership, Executive Compensation, and the Board of Commissioners.

Investors will always carry out investment activities. Investments can be made through various businesses, one of which is through share ownership. A director or executive can buy shares in the company he leads. Executive share ownership, namely shares purchased by the executive. Executive share ownership becomes a part of ownership itself based on the number of shares invested in a company. Share ownership has the right to the company's profits in accordance with the portion of shares it has invested in the company.

Some research shows that executive share ownership has a significant effect on tax avoidance [5, 18, 20, 22], and [23]. Executive share ownership will make executives become aggressive in making decisions, especially regarding tax avoidance [5]. With executive share ownership, it is expected to increase the company performance by tax efficiency through tax avoidance. Vice versa, some other research shows that executive share ownership has no significant effect on tax avoidance [9] and [16]. Executive share ownership will make executives more careful when making decisions [16]. This decision includes making tax efficiency through tax avoidance practices. This is because if the decision can endanger the company, executives who have share ownership in a company will be affected by the decision.

The manager's role as the leader of the company will influence applicable company policies, including tax avoidance policies. By providing high compensation to the executive, it is hoped that they will be able to implement corporate tax efficiency. Compensation is a service fee provided by the company in the form of income in the form of money, including direct and indirect goods, and employees will receive the goods [7]. Executive compensation consists of stock options, basic salary, bonuses, and other personal and position benefits. Executive compensation can be used as a tool to motivate and monitor executives in order to maximize their wealth in a company. Executives will certainly prefer to make decisions that can benefit them. One of them is in terms of paying corporate taxes. Executives would certainly prefer to minimize the amount of taxes that the company must pay in order to get large compensation.

Some research shows that executive compensation has significant effect on tax avoidance [2, 5, 6, 13], and [29]. One of the most effective solution to reduce the amount of corporate tax can be done by providing compensation to executives [5]. Besides, by providing higher compensation can reduce tax expense that must be paid by the company [2]. This is because compensation can help align the interests of managers and shareholders [6]. Vice versa, some research shows that executive compensation has no significant effect on tax avoidance [14, 16, 17], and [24]. If executives receive higher compensation, it will reduce the possibility of tax avoidance [14]. This is because managers will not dare to take too much risk for tax avoidance. In addition, they also said that the bonus system in Indonesia was not able to motivate managers in making decisions about corporate taxes [17].

In a company, the role of a board of commissioners is needed as the supervisor of the company. An independent commissioner is a party not related to business or family with another member of the board of directors or commissioners, controlling shareholder and the company itself. An independent commissioner in an organization is responsible for monitoring the implementation of the director's strategy so that it is hoped that an independent commissioner can minimize problems that may arise between the board of directors and shareholders. In addition, an independent commissioner can serve as a mediator between company owners and company management when determining company policies and strategies so as not to deviate, including determining tax-related policies. 
Some research indicates that independent commisioners have a significant effect on tax avoidance [22] and [27]. These results are in line with other research which shows that independent commisioners have a significant negative effect on tax avoidance [4, 6], and [23]. The performance of board commissioners can reduce tax avoidance practices [22]. This is because the more the number of independent commissioners owned, the more effective it is in monitoring and controlling the performance of the board of directors or managers. In contrast, other research shows that independent commissioners has no significant effect on tax avoidance [8, $12,15,16]$, and [26]. The role of independent commissioners is less effective in overseeing the operation of the company, including in determining tax efficiency policies [12]. This is because the independent commissioner is included in the board of commissioners of the company so that there is still a chance if the independent commissioner is unable to carry out their duties properly. So that companies can still have the potential to do tax avoidance.

Based on the phenomena and research gaps described above, this study aims to re-examine "The Influence of Executive Share Ownership, Executive Compensation, and the Board of Commissioners on Tax Avoidance ".

\section{Literature Review}

\subsection{Agency Theory}

Agency theory describes the contractual relationships between owners as principals who provide work to others as agents to provide services and delegate authority in making decisions to the agent concerned [11]. The conception of this theory shows that the conflict is caused by a conflict of interest between the owner as the principal and the agent concerned. It can be assumed that shareholders act only on the basis of the company's financial performance while agents are considered as recipients of financial compensation who can satisfy them.

Agency theory assumes that basically every human being is selfish on the basis of their individuality and will act in their personal interest. Agency theory also associates information asymmetry between managers as agents and as primary owners. Information asymmetry means that the owner and the manager of the company have different information about the company. Management is responsible for optimizing profits for the owner (principal) and satisfying their personal interests in order to maximize economic needs and psychological fulfillment. Meanwhile, shareholders will focus on increasing the value of their shares. So it can be said that in the company there are two conflicting interests where each party tries to achieve their welfare.

The relationship between agency theory and tax avoidance is a conflict between tax authorities (tax collectors) and company management (taxpayers) for the benefit of the company. Fiskus hopes to make big profits from tax collection, and agents hope the company will make a sizable profit with a smaller tax expense. This happens because the principal gives orders to the agent to minimize the amount of corporate tax, so that the company tax is lower than it should be. If the agent does not comply with the principal's interests, the agent will bear the agency cost.

\subsection{Tax Avoidance}

Tax avoidance is included in active tax resistance. Tax avoidance intended to decrease the corporate tax expense, but did not violate tax laws and regulations [25]. In simple terms, it can be said that tax avoidance is an effort to optimize profits legally and not violating provisions that take advantage of the weaknesses of applicable regulations so as to minimize the company's tax expense. Because of the tax cost, company owners tend to choose to actively take tax avoidance actions [24].

Tax avoidance is carried out safely and legally by taxpayers and does not conflict with applicable taxation policies, where the methods and techniques used often is using loopholes in taxation policies so that the amount of tax owed become small [27]. Weak laws, high tax rates, real injustice, and penalties that do not have a deterrent effect are the causes of tax avoidance [27].

\subsection{The Effect of Executive Share Ownership on Tax Avoidance}

Executive share ownership is part of the company's shareholders. The cash flow of a company will directly and indirectly be the expectations of executives. So that it allows executives to get benefit [5]. Executive share ownership can make executives aggressive in making decisions, including regarding tax avoidance. A research argue that executive share ownership has an effect on executives in making tax efficiency policies through tax avoidance practices [5]. This is because executives who are shareholders will benefit from corporate tax efficiency efforts. In addition, executives who are willing to take risks have a greater impact on tax avoidance practices than executives who are not willing to take risks. From the explanation, it can be concluded that executive share ownership can affect tax avoidance. Therefore, the formulation of the first hypothesis is as follows:

$\mathrm{H}_{1}$ : Executive share ownership has an effect on tax avoidance

\subsection{The Effect of Executive Compensation on Tax Avoidance}

Executive compensation, namely financial and nonfinancial fees that are distributed by company owners to an executive for the performance they have provided [21]. A research argued that one of the most effective solutions to reduce corporate taxes can be done by providing compensation to executives [5]. A person as an individual will take action if they got benefits from it. Thus, providing appropriate compensation for executives can effectively improve corporate tax efficiency. So it can be said that if the company provides high compensation to executives it will be able to increase corporate tax avoidance actions. On the other hand, a research argued higher compensation will decrease tax expense that must be paid by company [2]. From the 
explanation, it can be concluded that executive compensation can affect tax avoidance. Therefore, the formulation of the second hypothesis is as follows:

$\mathrm{H}_{2}$ : Executive compensation has an effect on tax avoidance

\subsection{The Effect of Independent Commissioners on Tax Avoidance}

An independent commissioner is a party that has no business or family relationship with a member of the board of directors and other commissioners, controlling shareholder and the company itself [16]. A research argued that the more the number of commissioners one has, the more effective it is in monitoring and controlling the performance of the board of directors or managers [22]. So it can be said that if the performance of the board of commissioners is more effective in conducting supervision, it can reduce tax avoidance practices. Besides, the other research also shows that independent commissioners have a positive influence on financial performance [10]. The existence of supervision by independent commissioners can reduce opportunistic behavior of management and fraud in the company. So that tax avoidance practices can be avoided. From the explanation, it can be concluded that independent commissioners can influence tax avoidance. Therefore, the formulation of the third hypothesis is as follows:

$\mathrm{H}_{3}$ : Independent commissioners have an effect on tax avoidance.

\section{Methodology}

\subsection{Dependent Variable}

The measurement that used to measure tax avoidance is Effective Tax Rates (ETR) which is tax expense divided by earnings before tax [16].

\subsection{Independent Variable}

a. Executive Share Ownership: the number of executive shares divided by the number of outstanding shares

b. Executive Compensation: Ln (total compensation for a year)

c. Independent Commisioners: the number of independent commissioners divided by the number of board of commissioners

\subsection{Population and Sample}

This research used manufacturing companies that listed on the Indonesia Stock Exhange as population. This research used a sampling technique with a purposive sampling method. The purposive sampling method is a sampling technique that is not random, but the selected sample must meet certain criteria. The criteria set in this research are as follows:

a. Manufacturing companies listed on the Indonesia Stock Exchange (IDX) for five consecutive years, namely the period of 2015-2019.

b. Companies that publish audited financial reports and annual reports for the 2015-2019 period.

c. Financial reports are presented in rupiah currency

d. Information regarding executive share ownership, executive compensation, and independent commissioners is disclosed in the annual reports and annual financial reports

\subsection{Data Analysis Technique}

This research used multiple linear regression analysis. The collected data will be analyzed using SPSS 26 software and Microsoft Excel 2010. The regression equation model in this research is as follows:

$$
\mathrm{Y}=\alpha+\beta_{1} \mathrm{X}_{1}+\beta_{2} \mathrm{X}_{2}+\beta_{3} \mathrm{X}_{3}+\mathrm{e}
$$

$$
\begin{aligned}
& Y=\text { Tax Avoidance } \\
& A=\text { Constant } \\
& \beta 1-\beta 3=\text { Regression Coefficient } \\
& X_{1}=\text { Executive Share Ownership } \\
& X_{2}=\text { Executive Compensation } \\
& X_{3}=\text { Independent Commissioner } \\
& e=\text { Error }
\end{aligned}
$$

\section{Analysis and Result}

\subsection{Description of the Research Object}

In this research, the research object is manufacturing companies that listed on the Indonesia Stock Exchange (IDX) during 2015-2019. The sample selection based on predetermined criteria are as follows:

Table 1. Sample Determination.

\begin{tabular}{lll}
\hline No & Sample Criteria & Amount \\
\hline 1. & Manufacturing companies listed on the Indonesia Stock Exchange (IDX) during the 2015-2019 period & 182 \\
2. & Manufacturing companies that were not listed for five consecutive periods, namely 2015-2019. & $(37)$ \\
3. & Manufacturing companies that do not present financial reports use the rupiah currency & $(30)$ \\
4. & Manufacturing companies that do not disclose data on executive share ownership, executive compensation, and independent & $(63)$ \\
5 & commissioners & 52 \\
6 & The number of manufacturing companies being sampled & 5 \\
7 & Number of years of research & 260 \\
8 & Outlier & 104 \\
9 & The total number of samples after outlier & 156 \\
\hline
\end{tabular}

Source: Secondary data processing (2021) 


\subsection{Descriptive Statistic Analysis}

Table 2. Descriptive Statistic Results After Outlier.

\begin{tabular}{|c|c|c|c|c|}
\hline Variable & Mean & Max & Min & SD \\
\hline Data Amount & 156 & 156 & 156 & 156 \\
\hline Tax Avoidance & 0.239056 & 0.3497 & 0.0750 & 0.479561 \\
\hline Executive Share Ownership & 0.023996 & 0.1075 & 0.0000 & 0.0330174 \\
\hline Executive Compensation & 23.263634 & 26.3641 & 20.7548 & 1.3556417 \\
\hline Independent Commissioner & 0.404143 & 0.8000 & 0.2000 & 0.928369 \\
\hline
\end{tabular}

Source: Secondary data processing (2021)

Tax avoidance is measured by dividing the tax expense against earnings before tax. The mean value of tax avoidance is 0.239056. The highest ETR value is 0.3497. Meanwhile, the lowest ETR value is 0.0750 . The standard deviation value for tax avoidance is 0.479561 .

Executive share ownership is measured by dividing the number of executive shares against the number of outstanding shares. The mean value of executive share ownership is 0.023996. The highest executive share ownership value is 0.1075 . Meanwhile, the lowest executive share ownership is 0.0000 . The standard deviation value for executive share ownership is 0.0330174 .

Executive compensation is measured using the natural logarithm of the total value of compensation received by the board of directors and the board of commissioners during a year. The mean value of executive compensation is 23.263634. The highest executive compensation value is 26.3641. Meanwhile, the lowest executive compensation value is 20.7548 . The standard deviation value for executive compensation is 1.3556417 .

Independent commissioner is measured by dividing the number of independent commissioners divided against the number of board of commissioners. The mean value of independent commissioner is 0.404143 . The highest independent commissioner value is 0.8000 . Meanwhile, the lowest independent commissioner value is 0.2000 . The standard deviation value for independent commissioner is 0 . 928369.

\subsection{Classic Assumption Test}

\subsubsection{Normality Test}

By looking at table 3, it can be seen that the significance value shows the number 0.281 where the number is more than 0.05 . So it can be concluded that the data is normally distributed.

Table 3. Kolmogorov-Smirnov Test Results.

\begin{tabular}{llll}
\hline Information & $\mathbf{N}$ & Asymp. Sig (2-tailed) & Conclusion \\
\hline Model 1 & 156 & 0.281 & Normal \\
\hline
\end{tabular}

Source: Secondary data processing (2021)

\subsubsection{Autocorrelation Test}

Table 4. Autocorrelation Test Results.

\begin{tabular}{ll}
\hline Model & Durbin-Watson \\
\hline 1. & 1.817 \\
\hline
\end{tabular}

Source: Secondary data processing (2021)

From table 4 above, the durbin-watson number has a dw value of 1.817 . Furthermore, the value is compared by looking at the table watson durbin position. The amount of data $(\mathrm{N})$ in this research is 156 and the number of independent variables $(\mathrm{K})$ is 3 . This research used a significance value of $5 \%$. So that the value of du is 1.7776 and $\mathrm{dl}$ is 1.6992 . By comparing the values at the watson durbin position it can be concluded if $\mathrm{du}<\mathrm{dw}<4$ $\mathrm{du}$ or $1.778<1.817<2.222$. So it can be interpreted that there is no autocorrelation in the regression model of this research.

Table 5. Multicollinearity Test Results.

\begin{tabular}{llll}
\hline Model & & Collinearity Statistics & \\
\hline $\mathbf{1}$ & Constant & Tolerance & VIF \\
\hline & Executive Share Ownership & 0.973 & 1.028 \\
& Executive Compensation & 0.916 & 1.091 \\
& Independent Commissioner & 0.927 & 1.079 \\
A. Dependent Variable: Tax Avoidance & & \\
\hline
\end{tabular}

Source: Secondary data processing (2021)

\subsubsection{Multicollinearity Test}

From table 5 above, it can be seen that the multicollinearity test of all independent variables shows that all independent variables have a tolerance value of more than 0.10 and also a VIF value of less than 10 . So it can be concluded that there is no correlation between independent variables or in this research multicollinearity does not occur, which means that the regression model has met the multicollinearity assumption
Table 6. Glejser Test Results.

\begin{tabular}{lll}
\hline & Model & Sig \\
\hline & Constant & \\
1. & Executive Share Ownership & 0.078 \\
& Executive Compensation & 0.113 \\
Dependent Variable: Abs_RES & 0.182 \\
\hline
\end{tabular}

Source: Secondary data processing (2021) 


\subsubsection{Heteroskedasticity Test}

From table 6 above, the significance value of all variables shows a number of more than 0.05 . So it can be concluded that the regression model in this research does not occur heteroscedasticity.

Table 7. Determination Coefficient Test Results.

\begin{tabular}{lllll}
\hline Model & R & R Square & Adjusted R Square & Std. Error of the Estimate \\
\hline 1 & $0.222^{\mathrm{a}}$ & 0.049 & 0.031 & 0.00364 \\
\hline
\end{tabular}

Source: Secondary data processing (2021)

\subsection{Hypothesis Testing}

\subsection{1. $R^{2}$ Test}

From table 7 above, the Adjusted R Square value shows the number of 0.031 . So it can be concluded that the percentage of the influence of the independent variables (executive share ownership, executive compensation, and independent commissioners) on tax avoidance as the dependent variable is only $3.1 \%$. The remaining $96.9 \%$ can be influenced by other factors that are not used in this research, such as largest share ownership, institutional ownership, profitability, company size, etc.

Table 8. T Statictical Test Results.

\begin{tabular}{|c|c|c|c|c|c|c|}
\hline \multirow{2}{*}{\multicolumn{2}{|c|}{ Model }} & \multicolumn{2}{|c|}{ Unstandardized Coefficients } & \multicolumn{3}{|c|}{ Standardized Coefficients } \\
\hline & & B & Std. Error & Beta & $\mathbf{t}$ & Sig \\
\hline \multirow{4}{*}{1} & (Constant) & 0.122 & 0.067 & & 1.822 & 0.070 \\
\hline & Executive Share Ownership & 0.119 & 0.118 & 0.082 & 1.015 & 0.312 \\
\hline & Executive Compensation & 0.013 & 0.007 & 0.165 & 1.975 & 0.050 \\
\hline & Independent Commissioner & -0.052 & 0.043 & -0.101 & -1.215 & 0.226 \\
\hline
\end{tabular}

Source: Secondary data processing (2021)

\subsubsection{T Test}

From table 8 above, the resulting t-test value is calculated. This research used 156 data $(\mathrm{N})$ and three independent variables $(K)$. To find the $t$ table value, the formula is $\mathrm{df}=\mathrm{N}$ - K. Based on this formula, $\mathrm{df}=156-3=153$. So that the $\mathrm{t}$ value is obtained. The table in the $t$ distribution table is 1.97559 .

Based on the $t$ calculation, the executive share ownership variable has a $t$ value of 1.015 with a significance value of 0.312 . While the $t$ table value is 1.97559 . From this value it is known that the value of $t$ table is greater than $t$ count ( $t$ count $<\mathrm{t}$ table). In addition, the significance value is more than 0.05 . So it can be concluded if Ho is accepted and $\mathrm{Ha}$ is rejected. This means that executive share ownership has no significant effect on tax avoidance.

Based on the $t$ calculation, the executive compensation variable has a t value of 1.975 with a significance value of 0.050 . While the t table value is 1.97559 . From this value it is known that the value of $t$ table is greater than $t$ count ( $t$ count $<\mathrm{t}$ table). In addition, the significance value is from 0.05 . So it can be concluded that Ha is accepted and Ho is rejected. This means that executive compensation has a significant positive effect on tax avoidance.

Based on the $t$ calculation, the independent commissioner variable has a $t$ value of -1.215 with a significance value of 0.226 . While the $t$ table value is 1.97559 . From this value it is known that the value of $t$ table is greater than $t$ count ( $t$ count $<\mathrm{t}$ table). In addition, the significance value is more than 0.05 . So it can be concluded that Ho is accepted and $\mathrm{Ha}$ is rejected. This means that independent commissioners have no significant effect on tax avoidance.

\section{Discussion}

\subsection{The Effect of Executive Share Ownership on Tax Avoidance}

Based on the results of the hypothesis testing that has been done, it shows that executive share ownership has no effect on tax avoidance. This can be seen from the table value which is greater than the calculated $t$ value and the significance value which is greater than 0.05 . So it is found that the first hypothesis in this study which is executive share ownership has a significant effect on tax avoidance is rejected. This means that executive share ownership has no significant effect on tax avoidance.

The results of this study indicate that the board of directors who have share ownership in a company is not motivated to take actions that only bring personal benefits so that the company does not do tax avoidance. This may be due to the fact that the board of directors who own the company's shares understand the impact that will arise if the company is indicated to have committed tax avoidance. These results are in line with some research which stated that executive share ownership has no significant effect on tax avoidance [9] and [16]. A research argue that executive share ownership will make executives more careful when making decisions [16]. This decision includes making tax efficiency through tax avoidance practices. This is because if the decision can endanger the company, executives who have share ownership in a company will be affected by the decision.

On the other hand, the results of this study are not in line with some reseach which state that executive share ownership has a significant effect on tax avoidance $[5,18,20$, 
22], and [23].

\subsection{The Effect of Executive Compensation on Tax Avoidance}

Based on the results of hypothesis testing that has been done, it is found that the second hypothesis in this study is accepted. This means that executive compensation has a significant positive effect on tax avoidance. This can be seen from the $t$ table value which is greater than the calculated $t$ value and the significance value is 0.05 . The results of this study are in line with some research which stated that executive compensation has a significant effect on tax avoidance [2, 5, 6, 13], and [29].

A research argue that one of the effective efforts to reduce corporate taxes can be done by providing compensation to executives [5]. In addition, high compensation can reduce the tax expense that the company must pay [2]. On the other hand, the results of this study are not in line with some research which show that executive compensation has no effect on tax avoidance [14, 16, 17], and [24].

However, keep in mind that Indonesia used a single rate of $25 \%$ for corporate income tax during the 2010-2019 period. This means that the tax rate is fixed and will always be the same in accordance with the applicable rules or regulations. So it is somewhat less valid to conclude that if the company has an ETR value that is getting smaller and below $25 \%$, it is categorized as doing tax avoidance. Of course, the company will still pay taxes at a fixed rate of $25 \%$ of its total profit.

If a company has an ETR value below $25 \%$, it is because of the Deferred Tax Asset, not because the company is doing tax avoidance. Deferred Tax Asset, namely the amount of income tax that can be recovered in future periods due to deductible temporary differences, accumulated tax losses that have not been compensated, and accumulated untapped tax credits [1]. In PSAK 46 regulates how companies regulate income tax $(\mathrm{PPh})$ in their financial statements. Both in the statement of financial position and statement of profit or loss and other comprehensive income [1]. With PSAK 46, management is given the freedom to determine accounting policies that will be used to assess deferred tax assets in their financial statements. So this can be used to indicate whether the company is doing profit manipulation or not in its financial statements [1].

\subsection{The Effect of Independent Commissioners on Tax Avoidance}

Based on the results of the hypothesis testing that has been done, it shows that independent commissioners have no effect on tax avoidance. This can be seen from the $t$ table value which is greater than the calculated $t$ value and the significance value which is greater than 0.05 . So it is found that the third hypothesis in this study, namely the independent commissioner has a significant effect on tax avoidance is rejected. This means that independent commissioners have no significant effect on tax avoidance.

The results of this study indicate that the role of independent commissioners is quite effective in supervising the running of the company. In addition, it can be said that independent commissioners tend not to be influenced by actions taken by company management. Independent commissioners who come from outside management and have no affiliation with anyone in the company tend to encourage company management to disclose wider information to shareholders.

The results of this study are in line with some research which indicates that independent commissioners has no significant effect on tax avoidance $[8,12,15,16]$, and [26]. A research argued that the role of independent commissioners is less effective in overseeing the operation of the company, including in determining tax efficiency policies [12]. This is because the independent commissioner is included in the board of commissioners of the company so that there is still a chance if the independent commissioner is unable to carry out their duties properly. So that companies can still have the potential to do tax evasion. On the other hand, the results of this study are not in line with some research which stated that independent commissioners have a significant effect on tax avoidance [22] and [27].

\section{Conclusion}

Based on the results and discussion, the conclusion is executive share ownership and executive compensation has no significant effect on tax avoidance. Meanwhile, executive compensation has a positive significant effect on tax avoidance. In addition, the adjusted $\mathrm{R}$ square shows $3,1 \%$ which means that there are still other factors that influence besides the factors used in this research. The limitation of this research are not all the board of directors have share ownership in the company, not all population meet the criteria, many companies do not specify in detail the amount of executive compensation both in terms of type and amount, there are several companies that do not published financial reports and annual reports that have been audited for five years, and measurements using ETR proxy turn out to be less valid as a measure of tax avoidance. With these limitations, suggestions for future research are to use the BTD (Book Tax Difference) measurement to measure tax avoidance, and use samples from other sectors so that the results can be more generalized. Then the suggestions for the government are to do more supervision regarding tax avoidance practices and pay more attention to other factors that can affect tax avoidance.

\section{References}

[1] Anasta, L. (2015). Analisisa Pengaruh Deferred Tax Asset, Deferred Tax Liabilities dan Tingkat Hutang Terhadap Manajemen Laba Pada Perusahaan Sub Sektor Industri Makanan dan Minuman di Indonesia. Jurnal Telaah Akuntansi Dan Bisnis, IV (02), 250-270.

[2] Armstrong, C. S., Blouin, J. L., Jagolinzer, A. D., \& Larcker, D. F. (2015). Corporate Governance, Incentives, and Tax Avoidance. Journal of Accounting and Economics. https://doi.org/10.1016/j.jacceco.2015.02.003 
[3] Febrantara D. (2020). Menggali Isu Penghindaran Pajak dari Beragam Perspektif. Diakes: tanggal 28 Oktober 2020. Dari https://news.ddtc.co.id/menggali-isu-penghindaran-pajak-dariberagam-perspektif-21670?

[4] H Lionita, A., \& Kusbandiyah, A. (2017). Pengaruh Corporate Social Responsibility, Profitabilitas, Leverage Dan Komisaris Independen Terhadap Praktik Penghindaran Pajak Pada Perusahaan Yang Terdaftar Di BEI. Kompartemen. Vol. XV, No. 1, Maret 2017.

[5] Hanafi, U., \& Harto, P. (2014). Analisis Pengaruh Kompensasi Eksekutif, Kepemilikan Saham Eksekutif Dan Preferensi Risiko Eksekutif Terhadap Penghindaran Pajak Perusahaan. Diponegoro Journal of Accounting, 3 (2). 1-11.

[6] Hariyanto, F., \& Utomo, D. C. (2018). Pengaruh Corporate Governance dan Kompensasi Eksekutif Terhadap Agresivitas Pajak. Diponegoro Journal of Accounting, 7 (4), 1-14.

[7] Hasibuan, M. S. P. (2017). Manajemen Sumber Daya Manusia Edisi Revisi Jakarta: Bumi Aksara.

[8] Hijriani, A. N., Latifah, S. W., \& Setyawan, S. (2017). Pengaruh Koneksi Politik, Dewan Komisaris dan Karakteristik Perusahaan terhadap Penghindaran Pajak (Perusahaan BUMN Yang Terdaftar di Bursa Efek Indonesia). Jurnal Reviu Akuntansi Dan Keuangan, 4 (1), 525-534. https://doi.org/10.22219/jrak.v4i1.4924

[9] Jamei, R. (2017). Tax Avoidance and Corporate Governance Mechanisms: Evidence from Tehran Stock Exchange. International Journal of Economics and Financial Issues, 7 (4), hal.638-644.

[10] Jaya, A. D., Zulfikar, R., Astuti, K. D., Sultan, U., \& Tirtayasa, A. (2018). Pengaruh Komisaris Independen Dan Kepemilikan Manajerial Terhadap Kinerja Keuangan Dengan Konservatisme Akuntansi Sebagai Variabel Intervening. EQUITY, 21 (1), 81-92.

[11] Jensen, M. C., \& Meckling, W. H. (1976). Theory Of The Firm: Managerial Behavior, Agency Costs And Ownership Structure. Journal of Financial Economics, 3, 305-360. https://doi.org/10.1016/0304-405X(76)90026-X

[12] Kusufiyah, Y. V., \& Anggraini, D. (2019). Peran Komisaris Independen, Ukuran Perusahaan, Kinerja Keuangan dan Leverage Terhadap Usaha Penghindaran Pajak. E-Jurnal Akuntansi Universitas Udayana, 26 (2), 1601-1631. https://doi.org/10.24843/eja.2019.v26.i02.p28

[13] Nugraha, M. I., \& Mulyani, S. D. (2019). Peran Leverage Sebagai Pemediasi Pengaruh Karakter Eksekutif, Kompensasi Eksekutif, Capital Intensity, dan Sales Growth Terhadap Tax Avoidance. Jurnal Akuntansi Trisakti, 6 (2), 301-324.

[14] Nugroho, R., \& Rosidy, D. (2019). Pengaruh Komisaris Independen dan Kompensasi Eksekutif Terhadap Agresivitas Pajak. Jurnal Info Artha, 3 (1), 55-65. https://doi.org/10.31092/jia.v3i1.563

[15] Prasetyo, I., \& Pramuka, B. A. (2018). Pengaruh Kepemilikan Institusional, Kepemilikan Manajerial, dan Proporsi Dewan Komisaris Independen terhadap Tax Avoidance. Jurnal Ekonomi, Bisnis, Dan Akuntansi, 20 (2). https://doi.org/10.32616/jbr.v1i2.64

[16] Prayogo, K. H., \& Darsono. (2015). Faktor-Faktor Yang Berpengaruh Terhadap Penghindaran Pajak Perusahaan. Diponegoro Journal of Accounting, 4, 1-12.
[17] Puspita, S. R., \& Harto, P. (2014). Pengaruh Tata Kelola Perusahaan Terhadap Penghindaran Pajak. Diponegoro Journal of Accounting, 3, 1-13.

[18] Putri, A. A., \& Lawita, N. F. (2019). Pengaruh Kepemilikan Institusional dan Kepemilikan Manajerial Terhadap Nilai Perusahaan. Jurnal Akuntansi Dan Ekonomika, 9 (1), 68-75. https://doi.org/10.32795/widyaakuntansi.vli1.249

[19] Setiawan D. (2020). Penerimaan Pajak 2019 Capai 84,4\% dari Target, Ini Data Lengkapnya. Diakses: tanggal 28 September 2020. From https://news.ddtc.co.id/penerimaan-pajak-2019capai--844-dari-target-ini-data-lengkapnya-18309?

[20] Shiddiq, M., \& Rahmawaty. (2018). The Influence of Leverage, Executive Incentives, Managerial Ownership on Tax Aggressiveness (Study in Manufacturing Companies Listed on Idx Year 2012-2014). Jurnal Ilmiah Mahasiswa Ekonomi Akuntansikuntansi, 3 (3), 494-504.

[21] Suherman, S., Pardede, Y. Y. P., \& Mardiyati, U. (2016). Pengaruh Kinerja Perusahaan, Corporate Governance, Dan Karakteristik Eksekutif Terhadap Kompensasi Eksekutif. Jurnal Keuangan Dan Perbankan, 20 (1), 1-9.

[22] Sunarsih, U., \& Oktavia, A. R. (2016). Pengaruh Corporate Governance Terhadap Tax Avoidance Pada Perusahaan Pertambangan Yang Terdaftar Di Bei. Jurnal Reviu Akuntansi $\begin{array}{llll}\text { Dan Keuangan, } & 6 & \text { (2), } & \text { 923-932. }\end{array}$ https://doi.org/10.22219/jrak.v6i2.05

[23] Sunarsih, U., \& Oktaviani, K. (2016). Good Corporate Governance in Manufacturing Companies Tax Avoidance. ETIKONOMI, $\quad 15 \quad$ (2), 85-96. https://doi.org/10.15408/etk.v15i2.3541

[24] Tandean, V. A., \& Winnie. (2016). The Effect of Good Corporate Governance on Tax Avoidance : An Empirical Study on Manufacturing Companies Listed in IDX period. Asian Journal of Accounting Research, 1, 28-38.

[25] Utama, F., Kirana, D. J., \& Sitanggang, K. (2019). Pengaruh Penghindaran Pajak Terhadap Biaya Hutang Dan Kepemilikan Institusional Sebagai Pemoderasi. Jurnal Bisnis Dan $\begin{array}{llll}\text { Akuntansi, } & 21 & \text { (1), }\end{array}$ https://doi.org/10.34208/jba.v21i1.425

[26] Wijayanti, A., Wijayanti, A., \& Samrotun, Y. C. (2017). Pengaruh Karakteristik Perusahaan, Good Corporate Governance Dan Corporate Social Responsibility Terhadap Penghindaran Pajak. ECONOMICA, 5 (2), 113-127. https://doi.org/10.22202/economica.2017.v5.i2.383

[27] Wulansari, N., \& Dewi, H. R. (2017). Pengaruh Kepemilikan Institusional, Proporsi Komisaris Independen, Komite Audit, Konservatisme Akuntansi, Pertumbuhan Penjualan dan Leverage Terhadap Penghindaran Pajak. Simposium Nasional Akuntansi XX, Jember.

[28] Yanti D. (2019). Sri Mulyani: Batas Dunia Makin Tipis, Ada Risiko Penghindaran Pajak. Acsess: April 4, 2020. From https://money.kompas.com/read/2019/08/21/121800626/srimulyani--batas-dunia-makin-tipis-ada-risiko-penghindaranpajak

[29] Yuwono, \& Fuad. (2019). Pengaruh Corporate Governance dan Kompensasi Eksekutif Terhadap Agresivitas Pajak. Diponegoro Journal of Accounting, 8 (3), 1-12. 